\title{
A COVID-19 PANDÉMIA MIATT BEVEZETETT KIJÁRÁSI TILALOM HATÁSA SEGÍTŐ FOGLALKOZÁST TANULÓ ERDÉLYI, MAGYAR EGYETEMISTÁK EGÉSZSÉGMAGATARTÁSÁRA
}

\section{IMPACT OF THE CURFEW IMPOSED DUE TO THE COVID-19 PANDEMIC ON THE HEALTH BEHAVIOR OF HUNGARIAN STUDENTS FROM TRANSILVANIA}

\author{
Albert-Lőrincz Enikő, Albert-Lőrincz Csanád
}

\begin{abstract}
Due to the COVID-19 pandemic it has become necessary a consciously focus on mental health condition too. In our study, we discuss how the crisis situation affected the health status of social work university students caused by the change of lifestyle during the state of emergency and the lock-down. We are highlighting what they have done to protect their health so that they can maintain their functional condition after 52 days of general lock-down in Romania. Among other things, we have shown, for example, that maintaining a daily routine activity is very important, and the performance of tasks and the energy level of the subjects are related. The importance of the supportive power of the family has been also proven. Examination of the cumulated variables of emotional life, due to emotional regulations, has indicated a lack of extreme emotions. In terms of functional wellbeing, respondents maintained their normal functionality by performing regularly their old and new daily tasks. Our goal was to draw attention to the fact that crisis situations should be managed with care and attention, consciously used techniques, emotional control, and purposeful use of resources in order to avoid damage to physical and mental health.
\end{abstract}

Keywords: crisis, lock-down, lifestyle change, health behavior

\section{Bevezetés}

\subsection{Keret feltételek}

Az egészségügyi világjárvány általánosan előtérbe helyezte az egészséggel való törődést (WHO 2020. árpilis 24). Jelen tanulmányban azt mutatjuk be, hogy hogyan alakult néhány segítőfoglalkozás-szakos erdélyi magyar egyetemista egészségmagatartása a preventív-korlátozó intézkedések időszakában. A sajátos helyzetben tanúsított egészségmagatartás jellemzőinek bemutatását két szempontból is fontosnak tartjuk a pedagógusok számára. Az egyik szempontunk az, hogy a vizsgált fiatalok lelkiállapotának és megküzdési törekvéseinek ismerete hozzájárulhat a pedagógusok és a szociális szakemberek - akik a pandémia idején, a pedagógusokhoz hasonlóan, szintén folytatták tevékenységüket - egymás jobb megismeréséhez, közeledéséhez. Erre egyre nagyobb szükség van, mert különösen krízis helyzetben, az iskolákra háruló feladatokat a pedagógusok és a segítőszakemberek közös erével tudják ellátni. A másik szempontunk az, hogy szeretnénk felhívni a figyelmet arra, hogy az egészséget befolyásoló tényezők - az öröklött tulajdonságok (20 százalék), az életmód (40 százalék), a környezet (25 százalék) és az egészségügyi ellátás (15 százalék) (Simon, 2009) - nagy része megváltozott a kijárási tilalom hatására. Felborult az életmód, megváltozott a környezet, az egészséget befolyásoló tényezők $80 \%$-a változást szenvedett, ami újra alkalmazkodást 
igényel. Mindez krízisbe sodorta az egyéneket, az intézményeket, nagy kihívás volt a gazdaság és a politikus mellett, az egészségügy, a szociális szakmák és az oktatás számára is. A hagyományos teendök mellett, szembe kellett nézni az online oktatás nehézségeivel is. Az élet több területén, így az oktatásban is fontos az újraszabályozás és az, hogy a pedagógusok tudatosan figyeljenek egészségi állapotukra, csakis is végezhetik el azt a feladatot, amely a helyi közösségek elvárnak tőlük. A kijárási tilalom feloldása nem jelenti a krízis végét, szeptembertől is szükség lesz az előre nem látható kihívások kezelésére. Erre pedig tudatosan kell készülni. Tanulmányunkkal ehhez szeretnénk hozzájárulni.

A kutatás előzményei összefoglalva: 2020 március 25-től május 15-ig, a járvány robbanásszerü terjedésének megelőzése céljából, Romániában az éjszakai kijárási tilalmat felváltotta az általános kijárási tilalom (195. sz. Elnöki Dekrétum 2020 március 16-ról). A román hatóságok szigorúbb intézkedéseket vezettek be a magyarországi korlátozásokhoz képest, sőt még a katonaságot is mobilizálták a rendfenntartás érdekében. A kijárási tilalom azt jelentette, hogy csak hat, pontosan meghatározott céllal lehetett elhagyni a lakhelyet (3. sz. Katonai Rendelet 2020 március 24-röl), valamint a lakhely elhagyásának indokáról saját felelősségre kitöltött írott nyilatkozatot kellett felmutatni. Sétára csak a lakhely közvetlen közelében (,a ház körül”) kerülhetett sor, a bevásárlások főként az élelmiszerek és szükséges gyógyszerek beszerzésére irányulhattak. A hatvanöt éven felülieknek, ez is csak bizonyos idősávokban volt lehetséges. A kijárási tilalom a mindennapi életet befolyásoló és átalakító tényezővé vált, egyre több stresszhelyzetet kellett a szervezetnek - úgy mentálisan, mint fizikálisan - kivédenie, feldolgoznia.

A mindennapi rutinok, a megszokott életvitel felborult. A megfertőződés kivédését szolgáló eljárások, tiltások sok esetben a lelki egyensúly felbomlását okozták, és ezen keresztül negatív hatással voltak a fizikai egészségre is (Vasiliu, 2020). Újra alkalmazkodásra volt szükség. Meg kell találni az adott körülményeknek megfelelő beilleszkedési lehetöségeket, eszközöket kellett találni az új feladatok, kihívások kezelésére. Meg kellett küzdeni az egymásnak sokszor ellentmondó, gyakran pánik hangulatot keltő információkkal, a bizonytalansággal, valamint a bezártsággal. Új helyzet volt, amire csak a múlt járványainak tapasztalata alapján lehetett felkészülni (Váradi, Ferenci, Falus, 2020). Ugyanakkor, ez az új helyzet egyfajta önismereti és fejlődési lehetőséget is biztosított, hiszen megtanított olyan helyzetmegoldásokra, amelyekkel a veszteségeket, valamint a krízist kezelni lehetetett.

Fokozottan érintve voltak az egyetemi hallgatók is, mert a szakdolgozatok megírása végett nem hagyhatták abba a terepgyakorlatot, ami áttevődött az online térbe. Számukra az is nehéz volt, hogy miután már megszokták az önálló életvitelt, a járvány miatt bevezetett online oktatás hazakényszerítette őket a családjukhoz, így a szülők elvárásaihoz fiatal felnőttként újra alkalmazkodniuk kellett.

\section{Elméleti modell és munkafogalmak meghatározása}

A kutatásunk során abból indultunk ki, hogy a bevezetett korlátozások és a kijárási tilalom az egyént krízishelyzetbe sodorták. Ennek következtében szükségszerüvé vált az új helyzethez való alkalmazkodás, ezt a reaktív képességet tekintjük rezilienciának (Békés, 2002). Amennyiben a személy megfelelően reziliensnek bizonyul, vagyis adaptálódik, akkor fenntartható a pozitív egészségmagatartás, ellenkező esetben megbetegszik.

Az egészségmagatartás az a viszony (Matarazzo, 1984), ahogyan az emberek az egészségük megtartásához, a megromlott egészség visszanyeréséhez vagy az idült betegségekkel való együttéléshez viszonyulnak. Azokra a tevékenységekre vonatkozik, amelyeket annak érdekében tesz az egyén, hogy egészségét megőrizze.

A kutatás elméleti háttere (Abelin, 1987) elméleti modelljére épül (1. ábra), amely szerint az egészségi állapotot több tényező együttes hatása (szocio-kulturális, szociális, politikai rendszer; az egészség személyi adottságai, a környezet, az egészségmagatartás) formálja. Ezek a tényezők a rendszerszemlélet alapján müködnek, ha az elemek szintjén változás történik, ez kihatással van magára az egészre, esetünkben az egészségi állapotra. A koronavírus járvány miatt kihirdetett tilalmak nyomán az egészséget meghatározó dimenziók több eleme is változást szenvedett. A felbomlott 
egyensúly visszaállításához kompenzációkra volt szükség, amit első körben, az egészségmagatartás terén hozott pozitív irányú változásokkal, ráerősítéssel lehetett elérni. Így kivédhetők a korai sérülések, megakadályozható a krízis elmélyülése illetve a traumatizáció.

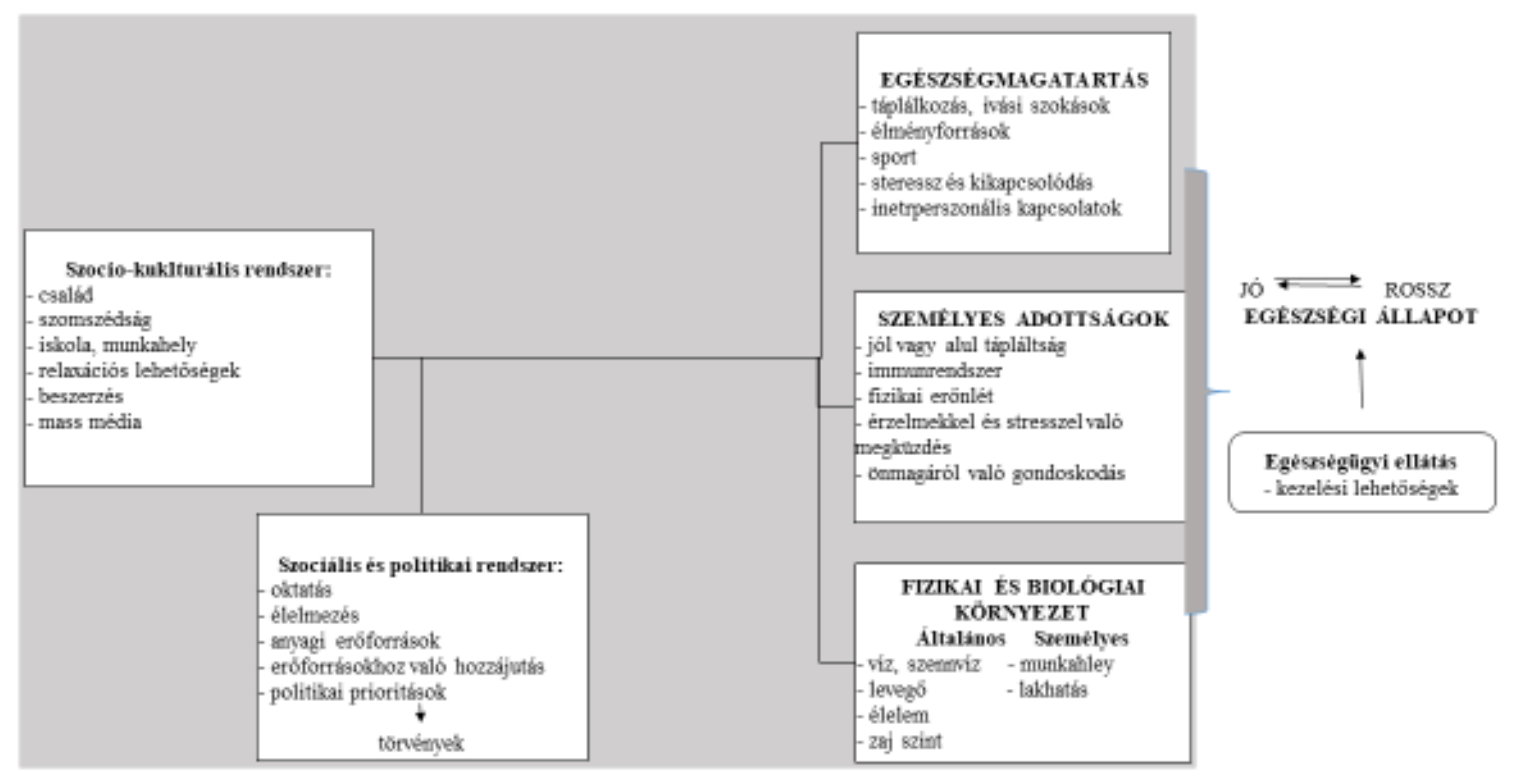

1. ábra. Az egészséget meghatározó tényezők. (Forrás: Abelin 1987, Factors that influence levels of health, 32.)

A kiegyensúlyozáshoz az egyén fel kellett ismerje, hogy változtatásokra van szüksége. A problémát adaptív módon, egyrészt a környezet, adott lehetőségeknek megfelelő megváltoztatása révén, másrészt a hozzáállás megváltoztatása, belső átrendezés, újrakeretezés útján érhették el. A jól megoldott krízisek az egyén megküzdő repertoárjának gazdagításához vezetnek, vagyis a krízisből megnövekedett adaptációs képességgel fognak kikerülni (Caplan, 1964).

\section{Célkitüzés}

Azokról a nehézségekről, amelyeket a korlátozások és tilalmak bevezetése jelentette a romániai népesség számára már korábbi tanulmányok is beszámoltak (Zamfir és Zamfir, 2020). A mi vizsgálatunk célja az volt, hogy rálátást nyerjünk a krízishelyzetnek, egy olyan fiatal felnőtt csoportra gyakorolt hatásairól, akik tudatosan készültek arra, hogy személyiségük lesz a legfontosabb munkaeszközük, ezért fokozottan kell figyelniük, vigyázniuk testi-lelki egészségük védelmére. Ezt a fiatal felnőtt csoportot, segítőszakmát tanuló egyetemi hallgatók képezték, akik majdnem 8 héten át (52 nap), beszámoltak életmódjukról, lelki- és egészségi állapotukról, valamint egészségmagatartásukról.

Azt feltételeztük, hogy képzésüknek köszönhetően - amelynek része a pályaszocializáció előkészítése és az egészségfejlesztés is - rendelkeznek olyan reziliens technikákkal, amelyek segíthetik abban, hogy sikeresen kezeljék az adott helyzetet. Olyan kérdéseket vetettünk fel számukra, amelyekre adott válaszokból és a naponta vezetett naplókból kiderült, hogy mit tettek egészségük megvédése érdekében, milyen védőfaktoroknak köszönhetően tudtak reziliensnek lenni, megtartani müködőképes állapotukat, mi az, ami pozitív ennek a kategóriának a hozzáállásában, és esetleg felmutatható mások számára is. 


\section{A kutatásban használt módszerek}

A kutatást a kijárási korlátozások és tilalmak időszakában végeztük, 2020 március 25 és május 16 között. Az adatokat három forrásból gyüjtöttük, és minden adatot kétszer vettünk fel a második és a nyolcadik héten. Eredményeinket minőségi adatelemzéssel (naplók érékelése) valamint mennyiségi számítások útján kaptuk.

Eszközeink: 1. A kutatás alanyai mindennap naplót vezettek (életérzésről, tevékenységekről, érzelmifizikai állapotukról, összesen 728 feljegyzés készült (52 nap x 14 diák). 2. Állapotfelmérő kérdőívet (G-Faktor), rövidített, módosított változat) 3. Kitöltöttek egy - a szerzők által szerkesztett helyzetértékelő kérdőívet is. Ebből azt tudhattuk meg, hogy milyen változásokat hozott a kijárási tilalom az életformában (hazaköltözés, személyi környezet, tevékenységek), az életérzésben (aggodalmak, szorongások természete, egészségtudat, stb.), az alkalmazkodást segítő erőforrások használatára vonatkozóan.

A kutatásban a Babes-Bolyai Tudományegyetem, magyar tannyelvü Szociális munka alapképzéséröl egy kis létszámú évfolyam, valamint a Tanácsadás mesteri másodéveseinek fele vett részt, azok, akik önként vállalták a naplóvezetést, illetve a kérdőívek kitöltését. Mivel a magyar tannyelvü szakok kis létszámú diákkal müködnek, a kutatásba 14 hallgatót tudtunk bevonni. Azért választottunk segítőfoglalkozást tanuló diákokat, mert képzésükhöz hozzátartozik az önmagukkal való munka (önismeret, készségfejlesztés, egészségfejlesztés). Feltételeztük, hogy tudatosan fognak bánni a krízishelyzettel, keresve az adaptív megoldásokat. A minta átlagéletkora huszonegy év, mindannyian nők voltak, 3 személy a párjával élt egy háztartásban, a többi korlátozások alatt a szüleihez költözött haza.

A kutatás kvantitatív adatelemzése a résztvevők önkitöltős kérdőívein alapul, melyben öt fö változócsoportot vizsgáltunk, melyek egyben megfelelnek a fö kutatási kérdésköreinknek. Ezen változócsoportok a következők: fizikai állapot, család-barátok, érzelmi jólét, funkcionális jólét és érzelmi állapotok. Az első négy változócsoportot 5-5 változóból építettük fel, az egészség tudat és az érzelmi élet esetében tíz változót alkalmaztunk. Erre azért volt szükség, hogy differenciáltabban láthassuk az érzelmi élet állapotainak - mint az adaptáció bázisa - változásit. Elvégeztük a változócsoportok elemzését, majd egymáshoz való viszonyukat is elemeztük. Az adatok feldolgozását SPSS statisztikai szoftverrel végeztük.

Megjegyeznénk, hogy nem állt módunkban kontrollcsoport felállítása (a szükség állapot és a kijárási tilalom bevezetése közötti tizenkét nap alatt nem találtunk olyan jelentkezőket, akik vállalták volna a napi feljegyzések készítését), ami a kutatás korlátjának tekinthető.

\section{Eredmények}

Jelen tanulmányban, a terjedelmi korlátok miatt, eltekintünk az összes adat bemutatásától. Felvázoljuk, hogy a vizsgálatban résztvevő egyetemi hallgatók milyen fizikai és szociális környezetben töltötték a kijárási tilalmat (a naplókra és a kérdőív szolgáltatta adatokra támaszkodva), majd röviden bemutatjuk, hogy mi jellemezte lelkiállapotukat (naplók tartalmi elemzése alapján), példákat adunk egy pár, általuk megjelölt erőforrásra (naplókból), bővebben, az egészségmagatartás jellemzőiről fogunk beszélni.

\subsection{Fizikai és szociális környezet}

Kutatási kérdéseink egy része arra vonatkozott, hogy milyen változásokat hozott az egyetemisták életében az, hogy a kijárási tilalom idejére vissza kellett költözzenek eredeti családjuk körébe (78.57\%-uk volt ebben a helyzetben), ennek következtében, hogyan változott életformájuk, tevékenységi köreik. Ebben a vonatkozásban azt tudtuk meg, hogy az online oktatás bevezetésekor (március 13) a legtöbb egyetemi hallgató hazaköltözött, a karatén bevezetése után (március 25) kiürültek a bentlakások. Két kolozsvári illetőségü diákon kívül, a többiek elhagyták az egyetemi várost.

A család körében, a közös légtérben töltött majdnem nyolc hét kihívásnak bizonyult, ami nemcsak a társas környezet váltással, hanem státuszváltozással is járt (64.28\%-nál), a szülők igyekeztek kontrollt 
gyakorolni a fiatal felett és bevonták őket a családi életbe (közös ebédek, vacsorák, hosszas beszélgetések), valamint a házimunkákba is $(85.71 \%)$. Tudni szerették volna, hogy mikor, mit csinálnak, és elvárták, hogy sok időt töltsenek a szülökkel (64.28\%). Gyakran jelentett problémát (42.85\%-nál) a tömbházak szúkös élettere, 60-80 négyzetmétert 3-6 személy kellett egymással megosszon, anélkül, hogy hosszabb időre, vagy a rendeletek által beszabályozott cél nélkül, elhagyhatták volna azt. A kijárási tilalom első heteiben kitört élelmiszer vásárlási láz azt eredményezte, hogy időlegesen eltünt pár alap élelmiszer, ami bezavart a család élelmezésébe (ezt $35.71 \%$ említi). Két székely kisvárosban az is előfordult, hogy a kijárási tilalom alatt akadozott a vízellátás (14.28\% teszi szóvá). A bezártság érzés leküzdésében sokat jelentett, ha volt a lakáshoz tartozó udvar, ami jellemző a vidéki kisvárosból vagy faluról származó hallgatók életkörülményeire (57.14\% említi). Ezek a körülmények teljesen másak voltak, mint a kolozsvári életterük és elfoglaltságaik.

\subsection{Lelkiállapot és erőforrások}

A kutatásban résztvevő személyek élethelyzete és életmódja a beszámolóik alapján teljesen megváltozott, ezeket a változásokat a lelkiállapot - szakaszokra bontható - változása kísérte.

A lelkiállapot alakulását a naponta készített beszámolók alapján elemeztük. A naplókban megjelenő érzések az idő folyamatában, több egymást követő csoportba oszthatók. Ezek a következők:

öröm-felszabadulás, hogy nem kell egyetemre járni, haza lehet menni, (erre utaló érzések: örülök, lazulok, élvezem, otthonosság, kikapcsolódás, felszabadultság, vakációs hangulat, stb.);

kijózanodás és elbizonytalanodás, intenzív érzelmi reakciókról és sok ambivalens érzésről számolnak be, egyensúlykeresés a pánik és a bagatellizálás között, (erre utaló érzések: félelem, depresszív tendenciák, sokkoltság, pánik hangulat, hitetlenség, zavarodottság, zürzavar, frusztráltság, harag, felháborodás, (utalnak az egymásnak ellentmondó információkra, a politikum zavart keltő megnyilvánulásaira, a hatósági túlkapásokra, a büntetésekre);

erőfeszítések és tagadás „nem is olyan nagy a veszély, mint a pánik”, uralni tudom a helyzetet”, (erre utaló érzések: erőlködés, megfeszülés, küzdelem, harag, elkeseredés, aggodalom, elszántság, kontroll utáni vágy, vívódás), gyakori a korlátozások megszegés (kirándulás az erdőbe, beteggondozás ürügyén piknikezés a nagyszülőkkel, mezőgazdasági munkák ürügyén lazítás a hétvégi házban, rokonlátogatás átvágva a hegyen, a szomszéd falúba);

belátás, a helyzet elfogadása, erőforrás, támpontok keresése: önmagára és szeretteire való figyelés, kapcsolatrendezés, bensőségesség megélése, újra rendeződés, elfogadás, megtanulni vele élni vagy feladás (jellemző érzések: megnyugvás, remény, bizalom, jó kedv, elégedettség, felszabadultság, megbékélés, szeretet, hit és remény, stb.);

újra alkalmazkodás és készülés a jövőre, azt keresve, hogy hogyan talál vissza régi életének mozzanataihoz, illetve hogyan lehet egyensúlyban élni hosszantartó bizonytalanságban (jellemzö érzések: belenyugvás, megnyugvás, perspektíva érzés, jövő orientáltság, öröm, felszabadulás, harmónia, stb.). A hallgatók többsége, azt is megfogalmazta, hogy ezután már semmi sem fog ugyanaz lenni, új élet kezdődik, amibe át kell menteni a régiből, azt, ami élhető. Ehhez a gondolathoz szorongások is kapcsolódtak: „elszoktam a tömegtől”, „,nem merem majd megfogni a tárgyakat”, stb.

Az, hogy a megkérdezettek eljutottak az újrarendeződéshez az önmagukról való gondoskodás képességének köszönhető. Arra a kérdésre, hogy mi adott ehhez erőt, az alábbi válaszokat kaptuk: az élet szeretete, a hit, a barátok, a kedvesem, a humor és az élni akarás, a jóga/meditálás, a kreatív önkifejezés, a lakásban uralkodó jókedv, fókuszálás az összképre és a jövőre, olyan írások - videók, podcastek - amelyek új perspektívából közelítették meg a kialakult helyzetet. Továbbá segített a család, a barátok, a hobbyk, a kísérletezés, a jó kedv, a kitartás, a pozitív életszemlélet, az önbizalom, a korábban megélt nehézségek, azok az egykori reménytelen helyzetek, melyekből (szinte csodaszerüen) volt kiút. Erőt adott ,az a rengeteg jó, ami még rám vár”, ,az a tudás, amit még el tudok sajátítani”, „az újra találkozások reménye”, „a fizikai mozgás, az edzés”, „az, hogy szeretem az embereket és értük itthon maradok, tanulok”, „megerősít, hogy szeretetben vagyok”, írták napi a naplójába egy hallgató. 
Nagyon fontosnak tartjuk azokat a válaszokat, amelyek arra mutattak rá, hogy a fenti erőforrásokat azoknak a helyzeteknek a meghaladásához használták, amikor elbizonytalanodtak, elszomorodtak. Tudatosan állították le a negatív gondolatokat, és helyettük a fenti értékekbe, erőforrásokba kapaszkodtak. Ezen kívül, a pontos napirend és a rendszeres aktivitás fenntartotta a rezilienciát. Sokan hivatkoztak arra, hogy próbáltak értelmet adni a percnek, a napnak, keresték azt, amit tovább lendíthet. Igyekeztek tudatosan átélni az adódó örömeket, a mindennapban keresni a jót és a szépet, fenntartani a pozitív érzelmi állapotokat, szabályozni az érzelmi végleteket. Külső és belső erőforrásaikat használtak a helyzetkezeléshez, ahhoz, hogy megőrizhessék lelki harmóniájukat, életigénylö beállítódásukat. A begyüjtött válaszokból kitünik, hogy a nehézségek mellett nyereségesnek is tekintették az elvonulást, ami új lehetőséget is adott: az idővel való bánás megtanulását, a kapcsolatok erősödését, az önmagukra fordított többlet időt, a saját ritmus szerint élni, lehetőségét azt, hogy rájöttek a differenciálás a szelektálás jelentőségére, a lényeglátásra.

\subsection{Az egészségmagatartás jellemzői}

Az egészségmagatartást az állapotfelmérő, a G-Faktor [14] kérdőív változócsoportjainak elemzése alapján vizsgáltuk. Eredetileg a kérdőív 4 változócsoportot tartalmaz (fizikai állapot, család és barátokkal való viszony, érzelmi jólét, funkcionális jólét), mely csoportokat 5-5 változó ír le. A GFaktor kérdöívhez hozzárendeltünk egy 5 . változót is, amely az érzelmi állapotokat tükrözi, ebben a csoportban 10 változót alkalmaztunk. A kiegészítö 5. változócsoport bevezetésével az volt a célunk, hogy, míg az érzelmi jólét egy stabil jellemző, az érzelmi állapotok a változó hangulatokra mutatnak rá. A válaszokat minden esetben egy 5 fokozatú skálán mértuik, ahol válaszadóink az egyáltalán nem igaz és nagyon igaz közötti fokozatok közül választhattak. A változócsoportokon belül megvizsgáltuk a válaszok eloszlását, melyet átlagértékek (M) és a szórás (SD) jellemeznek. Az alábbiakban ezeket az eredményeket mutatjuk be.

\subsection{A fizikai állapot jellemzői}

A fizikai állapot felmérése érdekében az alábbi öt változót alkalmaztuk, amint az 1-es számú táblázatban, alább láthatjuk.

1. sz. táblázat - A fizikai állapot jellemzői

\begin{tabular}{|c|c|c|c|c|c|c|c|c|c|c|}
\hline & \multicolumn{2}{|c|}{$\begin{array}{c}\text { Egyáltalán nem } \\
\text { igaz }\end{array}$} & \multicolumn{2}{|c|}{ Egy kicsit igaz } & \multicolumn{2}{|c|}{$\begin{array}{c}\text { Valamennyire } \\
\text { igaz }\end{array}$} & \multicolumn{2}{|c|}{$\begin{array}{c}\text { Meglehetösen } \\
\text { igaz }\end{array}$} & \multicolumn{2}{|c|}{ Nagyon igaz } \\
\hline $\begin{array}{l}\text { Híján van az } \\
\text { energiám }\end{array}$ & 3 & $21,4 \%$ & 3 & $21,4 \%$ & 3 & $21,4 \%$ & 4 & $28,6 \%$ & 1 & $7,1 \%$ \\
\hline $\begin{array}{l}\text { Nehezen tudom } \\
\text { végezni a } \\
\text { feladataimat }\end{array}$ & 3 & $21,4 \%$ & 2 & $14,3 \%$ & 4 & $28,6 \%$ & 3 & $21,4 \%$ & 2 & $14,3 \%$ \\
\hline $\begin{array}{l}\text { Félek, hogy } \\
\text { megbetegszem }\end{array}$ & 3 & $21,4 \%$ & 4 & $28,6 \%$ & 7 & $50,0 \%$ & 0 & $0,0 \%$ & 0 & $0,0 \%$ \\
\hline $\begin{array}{l}\text { Fájdalmaim } \\
\text { vannak }\end{array}$ & 8 & $57,1 \%$ & 4 & $28,6 \%$ & 1 & $7,1 \%$ & 1 & $7,1 \%$ & 0 & $0,0 \%$ \\
\hline $\begin{array}{l}\text { Nyomasztónak } \\
\text { érzem a } \\
\text { környezetemet }\end{array}$ & 5 & $35,7 \%$ & 6 & $42,9 \%$ & 0 & $0,0 \%$ & 2 & $14,3 \%$ & 1 & $7,1 \%$ \\
\hline
\end{tabular}

A fenti eredményekből kiolvashatjuk, hogy a kutatásban résztvevő egyetemisták energiaszintje átlagosnak mondható, ugyanez igaz a feladatok elvégzéséhez szükséges teljesítményükre is. A vírusos megbetegedéstől általában nem félnek, sőt még szomatikus fájdalmak, pszichoszomatikus tünetek sem jelentkeznek náluk. Többségük nem érzi túlságosan nyomasztónak a környezetét. Összességében elmondható, hogy a fizikai állapotuk inkább jó-átlagos. A válaszokra adott összesített átlagértékek alapján felrajzolt görbe balra tolódik, ami azt jelenti, hogy változók szintjén megfogalmazott negatív érzések és állapotok kevésbé jellemzik őket. 


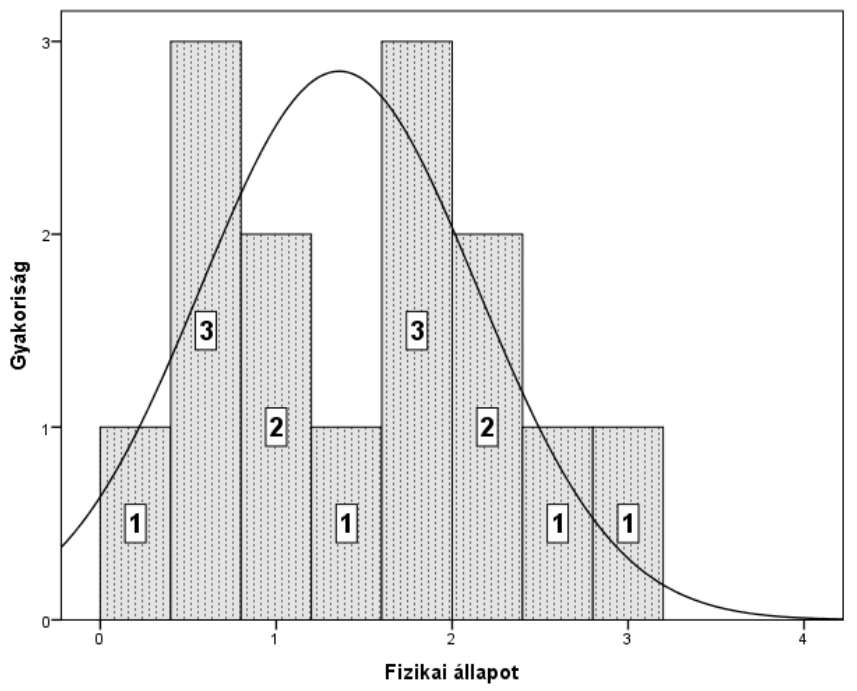

1. ábra - A fizikai állapot hisztogram típusú ábrázolása az szórási görbével

Az eloszlás vizsgálatát átlagok és szórás számításával vizsgáltuk, amit a 2 számú táblázat szemléltet. Minél kisebb az átlagérték, annál kevésbé jellemző rájuk az adott negatív érzés vagy állapot. Az eredmények szerint a legkevésbé jellemzőek az alanyainkra a szomatikus fájdalmak, sőt még a bezárt környezetüket is eléggé elviselhetőnek ítélték meg. Az energiaszintjük és a feladataik elvégzése jelenti számukra a legfőbb nehézséget, ugyanis a bezártság és az online oktatás felborította a napi rutinjukat.

2. táblázat - A fizikai állapot átlagainak és szórásának vizsgálata

\begin{tabular}{lcc}
\hline & Átlag & Szórás (SD) \\
\hline Híján van az energiám & 1,79 & 1,31 \\
\hline $\begin{array}{l}\text { Nehezen tudom végezni a } \\
\text { feladataimat }\end{array}$ & 1,93 & 1,38 \\
\hline Félek, hogy megbetegszem & 1,29 & 0,83 \\
\hline Fájdalmaim vannak & 0,64 & 0,93 \\
\hline $\begin{array}{l}\text { Nyomasztónak érzem a } \\
\text { környezetemet }\end{array}$ & 1,14 & 1,29 \\
\hline Összesített fizikai állapot & 1,36 & 0,79 \\
\hline
\end{tabular}

A fizikai állapotot öt változón keresztül mértük, valamint az ide vonatkozó változók közötti összefüggéseket Pearson féle korrelációs számításokkal vizsgáltuk a 3. számú táblázat szerint.

3. táblázat - A fizikai állapotot leíró változók közötti korrelációs összefüggések

\begin{tabular}{|c|c|c|c|c|}
\hline & $\begin{array}{c}\text { Nehezen tudom } \\
\text { végezni a } \\
\text { feladataimat }\end{array}$ & $\begin{array}{c}\text { Félek, hogy } \\
\text { megbetegszem }\end{array}$ & $\begin{array}{c}\text { Fájdalmaim } \\
\text { vannak }\end{array}$ & $\begin{array}{l}\text { Nyomasztónak } \\
\text { érzem a } \\
\text { környezetemet }\end{array}$ \\
\hline Híján van az energiám & $.626^{*}$ & .416 & .185 & .156 \\
\hline $\begin{array}{l}\text { Nehezen tudom végezni a } \\
\text { feladataimat }\end{array}$ & & .019 & .397 & .479 \\
\hline $\begin{array}{l}\text { Félek, hogy } \\
\text { megbetegszem }\end{array}$ & & & .143 & -.185 \\
\hline Fájdalmaim vannak & & & & $.751^{* *}$ \\
\hline $\begin{array}{l}\text { *. A korreláció .05 szinten } \\
* * \text {. A korreláció } .01 \text { szinte }\end{array}$ & $\begin{array}{l}\text { gnifikáns (kétvég } \\
\text { zignifikáns (kétvé }\end{array}$ & & & \\
\hline
\end{tabular}

A fentiekböl kitünik, hogy összesen két esetben véltünk közepesen erős-erős pozitív korrelációs viszonyt felfedezni: a feladatok elvégzése és az alany energiája állnak összefüggésben $(r=.626, p<.05)$, vagyis akik úgy érzik, hogy kevés az energiájuk, nehezebben birkóznak meg a napi feladataikkal. A 
nyomasztó környezet és a fizikai fájdalmak is összefüggésben állnak ( $\mathrm{r}=.751, \mathrm{p}<.01)$, ez alátámasztja a környezeti körülmények hatását a fizikai állapotra.

\section{a) A családdal és barátokkal való viszony jellemzői}

A családdal és barátokkal való viszonyt szintén öt változón keresztuil vizsgáltuk. A vírushelyzetben fennálló korlátozások legnagyobb befolyással a társas kapcsolatokra voltak. A kutatásban résztvevő egyetemisták több időt töltöttek a családjukkal, mind annak elötte, viszont a barátaikkal csak online tarthatták a kapcsolatot.

4. táblázat - A családdal és barátokkal való viszony jellemzői

\begin{tabular}{|c|c|c|c|c|c|c|c|c|c|c|}
\hline \multirow[b]{2}{*}{$\begin{array}{l}\text { Szoros } \\
\text { kapcsolatban } \\
\text { vagyok a } \\
\text { barátaimmal online }\end{array}$} & \multicolumn{2}{|c|}{$\begin{array}{c}\text { Egyáltalán nem } \\
\text { igaz }\end{array}$} & \multicolumn{2}{|c|}{ Egy kicsit igaz } & \multicolumn{2}{|c|}{$\begin{array}{l}\text { Valamennyire } \\
\text { igaz }\end{array}$} & \multicolumn{2}{|c|}{$\begin{array}{l}\text { Meglehetősen } \\
\text { igaz }\end{array}$} & \multicolumn{2}{|c|}{$\begin{array}{l}\text { Nagyon } \\
\text { igaz }\end{array}$} \\
\hline & 0 & $0,0 \%$ & 2 & $14,3 \%$ & 2 & $14,3 \%$ & 3 & $21,4 \%$ & 7 & $50,0 \%$ \\
\hline $\begin{array}{l}\text { Családom támogat, } \\
\text { egyetértés van } \\
\text { közöttünk }\end{array}$ & 0 & $0,0 \%$ & 0 & $0,0 \%$ & 1 & $7,1 \%$ & 5 & $35,7 \%$ & 8 & $57,1 \%$ \\
\hline $\begin{array}{l}\text { Szeretteimhez közel } \\
\text { érzem magam }\end{array}$ & 0 & $0,0 \%$ & 1 & $7,1 \%$ & 5 & $35,7 \%$ & 4 & $28,6 \%$ & 4 & $28,6 \%$ \\
\hline $\begin{array}{l}\text { Magányosnak } \\
\text { érzem magam }\end{array}$ & 6 & $42,9 \%$ & 4 & $28,6 \%$ & 2 & $14,3 \%$ & 2 & $14,3 \%$ & 0 & $0,0 \%$ \\
\hline $\begin{array}{l}\text { Idegesítenek a } \\
\text { családtagjaim }\end{array}$ & 7 & $50,0 \%$ & 4 & $28,6 \%$ & 2 & $14,3 \%$ & 0 & $0,0 \%$ & 1 & $7,1 \%$ \\
\hline
\end{tabular}

A 4-es táblázat arra utal, hogy a megkérdezettek számíthatnak a családjuk támogatására és jó viszonyban vannak a családtagjaikkal, közel érzik öket magukhoz. Mi több, az is ritka, hogy az összezártság miatt, szeretteik idegesítővé válnának számukra. Mivel barátaikkal online tartották a kapcsolatot, a magányosság sem jellemző rájuk.

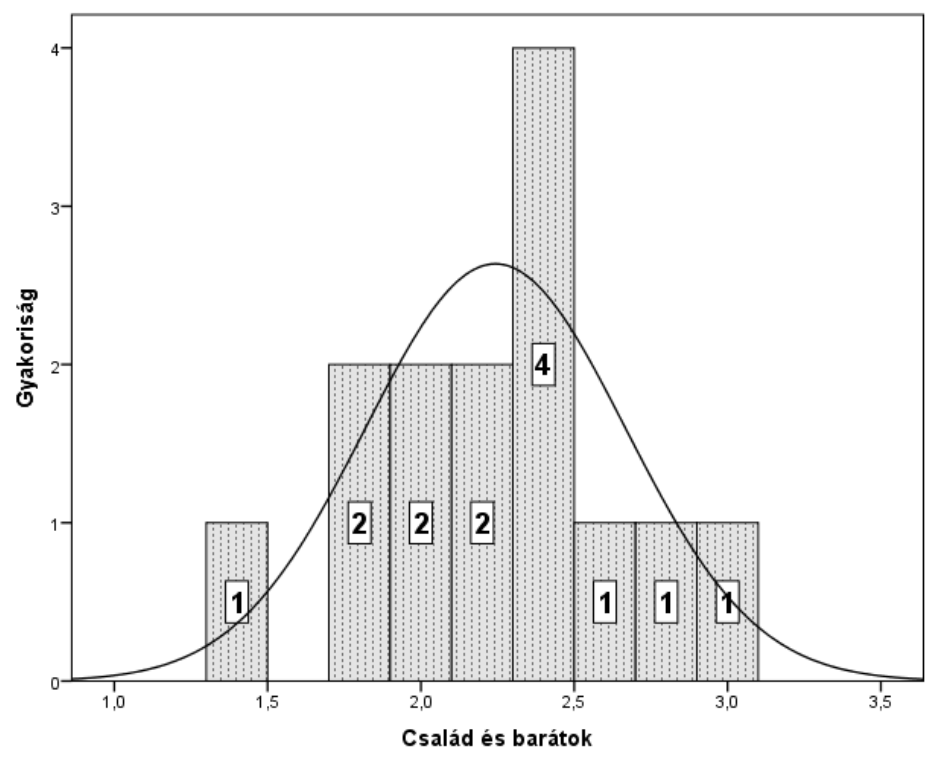

2. ábra - A családdal és barátokkal való viszony hisztogram típusú ábrázolása az szórási görbével

A válaszok eloszlásának vizsgálata (átlagok, szórás) arra enged következtetni, hogy az interperszonális kapcsolatok megfelelően müködtek a bezártság ideje alatt is. A 2. számú ábrán szereplő hisztogram 
szórási görbéje kiegyensúlyozottságra utal. Az átlagokat tekintve (5-ös táblázat) megerősítést kaptunk a már elhangzott kijelentéseinkre, ugyanis a család betöltötte támogató szerepét, valamint a barátokkal való kapcsolat nem szünetelt, hanem áttevődött az online térbe. Azonban megjegyzendő, hogy a legnagyobb mértékü szórás az ebbe a csoportban kaptuk, vagyis nem mindenkinek sikerült alkalmazkodnia az adott helyzethez.

5. táblázat - A családdal és barátokkal való viszony átlagainak és szórásának vizsgálata

\begin{tabular}{lcc}
\hline & Átlag & Szórás (SD) \\
\hline $\begin{array}{l}\text { Szoros kapcsolatban vagyok a } \\
\text { barátaimmal online }\end{array}$ & 3,07 & 1,14 \\
\hline $\begin{array}{l}\text { Családom támogat, egyetértés van } \\
\text { közöttünk }\end{array}$ & 3,50 & 0,65 \\
\hline Szeretteimhez közel érzem magam & 2,79 & 0,97 \\
\hline Magányosnak érzem magam & 1,00 & 1,11 \\
\hline Idegesítenek a családtagjaim & 0,86 & 1,17 \\
\hline Összesített család és barátok & 2,24 & 0,42 \\
\hline
\end{tabular}

A családdal és barátokkal való viszonnyal kapcsolatos változók közötti összefüggéseket Pearson féle korrelációs számításokkal vizsgáltuk.

6. táblázat - A családdal és barátokkal való viszonyt leíró változók közötti korrelációs összefüggések

\begin{tabular}{|c|c|c|c|c|}
\hline & $\begin{array}{l}\text { Családom } \\
\text { támogat, } \\
\text { egyetértés van } \\
\text { közöttünk }\end{array}$ & $\begin{array}{l}\text { Szeretteimhez } \\
\text { közel érzem } \\
\text { magam }\end{array}$ & $\begin{array}{l}\text { Magányosnak } \\
\text { érzem magam }\end{array}$ & $\begin{array}{l}\text { Idegesítenek a } \\
\text { családtagjaim }\end{array}$ \\
\hline $\begin{array}{l}\text { Szoros kapcsolatban } \\
\text { vagyok a barátaimmal } \\
\text { online }\end{array}$ & $-.570^{*}$ & -.054 & -.061 & .412 \\
\hline $\begin{array}{l}\text { Családom támogat, } \\
\text { egyetértés van közöttünk }\end{array}$ & & $.546^{*}$ & -.107 & $-.709^{* *}$ \\
\hline $\begin{array}{l}\text { Szeretteimhez közel } \\
\text { érzem magam }\end{array}$ & & & -.284 & -.299 \\
\hline $\begin{array}{l}\text { Magányosnak érzem } \\
\text { magam }\end{array}$ & & & & .416 \\
\hline \multicolumn{5}{|c|}{$\begin{array}{l}\text { *. A korreláció .05 szinten szignifikáns (kétvégü). } \\
\text { **. A korreláció .01 szinten szignifikáns (kétvégü). }\end{array}$} \\
\hline
\end{tabular}

A családdal és barátokkal való viszonyokat néhány összefüggést mutató változó jellemzi, amint az a 6os táblázatból kitünik. Akik szoros online kapcsolatot tartottak fenn a barátaikkal, azokat kevésbé támogatta a családjuk és kevésbé jellemző a családon belüli egyetértés. Ezt a „kifelé fordulást” egy közepesen erős negatív korrelációs együttható jelzi ( $\mathrm{r}=-.570, \mathrm{p}<.05)$. Mindezt alátámasztja az is, hogy ahol kisebb a támogatás és az egyetértés, ott idegesítőnek vélik fiatal alanyaink a családtagjaikat, amint ezt egy negatív előjelű erős korreláció bizonyítja $(\mathrm{r}=-.709, \mathrm{p}<.01)$. Értelemszerüen, akik erősebbnek a támogatást és az egyetértést, közelebb érzik magukhoz a családjukat, amire egy közepes erősségü pozitív korrelációs viszony $(\mathrm{r}=.546, \mathrm{p}<.05)$ mutat rá.

\section{b) Az érzelmi jólét jellemzői}

Az érzelmi jólét az egyik legfontosabb mutatója a kutatásban résztvevő fiatalok általános állapotának. Amint arra a 7-es számú táblázat adatai következtetni engednek, a vírushelyzetben elrendelt korlátozások kihatással vannak a kedélyállapotra, kiolvasható a lehangoltság és valamelyest a szomorúság megléte is. A helyzet miatt azonban nincs jele fokozott idegességnek, a bezártságot inkább jól kezelik az egyetemisták. A saját állapotuk rosszabbodása miatti aggodalom is kevésbé jellemző. 
7. sz. táblázat - Az érzelmi jólét jellemzői

\begin{tabular}{|c|c|c|c|c|c|c|c|c|c|c|}
\hline & \multicolumn{2}{|c|}{$\begin{array}{c}\text { Egyáltalán nem } \\
\text { igaz }\end{array}$} & \multicolumn{2}{|c|}{ Egy kicsit igaz } & \multicolumn{2}{|c|}{$\begin{array}{c}\text { Valamennyire } \\
\text { igaz }\end{array}$} & \multicolumn{2}{|c|}{$\begin{array}{c}\text { Meglehetősen } \\
\text { igaz }\end{array}$} & \multicolumn{2}{|c|}{$\begin{array}{l}\text { Nagyon } \\
\text { igaz }\end{array}$} \\
\hline Szomorú vagyok & 3 & $21,4 \%$ & 4 & $28,6 \%$ & 6 & $42,9 \%$ & 1 & $7,1 \%$ & 0 & $0,0 \%$ \\
\hline $\begin{array}{l}\text { A bezártság miatt } \\
\text { lehangolt vagyok }\end{array}$ & 1 & $7,1 \%$ & 2 & $14,3 \%$ & 6 & $42,9 \%$ & 4 & $28,6 \%$ & 1 & $7,1 \%$ \\
\hline Ideges vagyok & 4 & $28,6 \%$ & 4 & $28,6 \%$ & 2 & $14,3 \%$ & 3 & $21,4 \%$ & 1 & $7,1 \%$ \\
\hline $\begin{array}{l}\text { Megvagyok } \\
\text { elégedve, } \\
\text { ahogyan a } \\
\text { bezártságot } \\
\text { viselem }\end{array}$ & 1 & $7,1 \%$ & 2 & $14,3 \%$ & 2 & $14,3 \%$ & 5 & $35,7 \%$ & 4 & $28,6 \%$ \\
\hline $\begin{array}{l}\text { Aggódom, hogy } \\
\text { állapotom } \\
\text { rosszabbodni fog }\end{array}$ & 4 & $28,6 \%$ & 3 & $21,4 \%$ & 3 & $21,4 \%$ & 4 & $28,6 \%$ & 0 & $0,0 \%$ \\
\hline
\end{tabular}

Az érzelmi élet összesített változóinak eloszlási vizsgálata során az alábbi, 3-as ábra adataiból kiderült, hogy nincsenek szélsőséges állapotok és aggodalmak, sőt, mivel a görbe enyhén balra tolódik, vagyis a pozitív válaszok felé, a kutatásban résztvevő alanyok átlagosnál jobb érzelmi állapotban vannak.

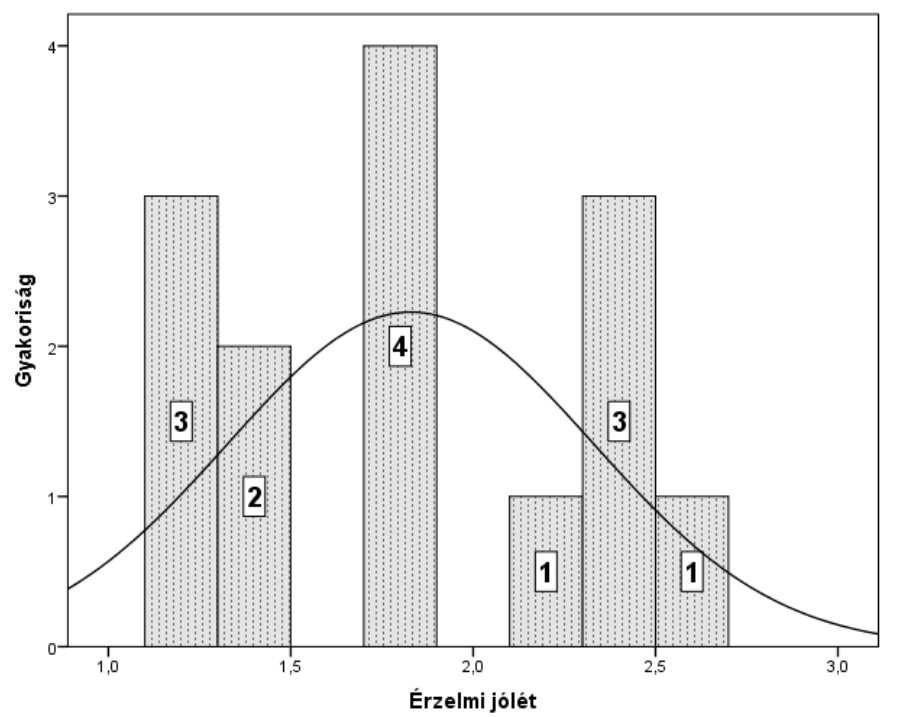

3. ábra - Az érzelmi jólét hisztogram típusú ábrázolása az szórási görbével

További információkat tudunk kiolvasni a 8-as számú táblázatból, ugyanis a legnagyobb átlagot a helyzet, valamint a bezártság kezelésével való elégedettség éri el, viszont ez fokozott lehangoltsággal jár. Az alanyaink véleménye leginkább a helyzet okozta idegesség tekintetében tér el, itt a legmagasabb a szórás aránya.

8. táblázat - Az érzelmi jólét átlagainak és szórásának vizsgálata

\begin{tabular}{lcc}
\hline & Átlag & Szórás (SD) \\
\hline Szomorú vagyok & 1,36 & 0,93 \\
\hline A bezártság miatt lehangolt vagyok & 2,14 & 1,03 \\
\hline Ideges vagyok & 1,50 & 1,34 \\
\hline Meg vagyok elégedve, ahogyan a bezártságot viselem & 2,64 & 1,28 \\
\hline Aggódom, hogy állapotom rosszabbodni fog & 1,50 & 1,22 \\
\hline Összesített érzelmi jólét & 1,83 & 0,50 \\
\hline
\end{tabular}


Az érzelmi jólétre irányuló változók közötti összefüggéseket Pearson féle korrelációs számításokkal vizsgáltuk.

9. táblázat - Az érzelmi jólétet leíró változók közötti korrelációs összefüggések

\begin{tabular}{|c|c|c|c|c|}
\hline & $\begin{array}{l}\text { A bezártság } \\
\text { miatt lehangolt } \\
\text { vagyok }\end{array}$ & Ideges vagyok & $\begin{array}{l}\text { Megvagyok } \\
\text { elégedve, } \\
\text { ahogyan a } \\
\text { bezártságot } \\
\text { viselem }\end{array}$ & $\begin{array}{l}\text { Aggódom, hogy } \\
\text { állapotom } \\
\text { rosszabbodni fog }\end{array}$ \\
\hline Szomorú vagyok & .023 & .462 & -.338 & .034 \\
\hline $\begin{array}{l}\text { A bezártság miatt } \\
\text { lehangolt vagyok }\end{array}$ & & $.557^{*}$ & $-.544^{*}$ & $.611^{*}$ \\
\hline Ideges vagyok & & & $-.605^{*}$ & .397 \\
\hline $\begin{array}{l}\text { Megvagyok elégedve, } \\
\text { ahogyan a bezártságot } \\
\text { viselem }\end{array}$ & & & & $-.615^{*}$ \\
\hline \multicolumn{5}{|c|}{ *. A korreláció .05 szinten szignifikáns (kétvégü). } \\
\hline
\end{tabular}

A fenti 9. számú táblázat alapján elmondható, hogy a bezártság elviselése és az ezzel járó lehangoltság között közepesen erős, negatív korrelációs összefüggés áll fenn ( $\mathrm{r}=-.544, \mathrm{p}<.05)$, ez arra utal, hogy akik jól viselik a bezártság érzését, kevésbé lehangoltak. Ehhez hasonlóan, a bezártság elviselése és a helyzetet idegesítő jellege, szintén közepes erősségü, negatív korrelációs viszonyban áll ( $\mathrm{r}=-.605, \mathrm{p}<.05)$, vagyis akik jól viselik a bezártságot, azok kevésbé idegesek. Akik könnyebben viselik a bezártságot, azok kevésbé aggódnak saját érzelmi állapotuk alakulása miatt, a két változó közötti korrelációs együttható negatív előjelü és közepesen erős ( $\mathrm{r}=-.615, \mathrm{p}<.05)$. Azon alanyok, akik aggódnak a saját állapotuk miatt, hajlamosabbak a lehangoltságra is. Ez esetben a két változó közötti korrelációs együttható pozitív és közepesen erős $(\mathrm{r}=.611, \mathrm{p}<.05)$.

\section{c) A funkcionális jólét}

A funkcionális jólét a napi teendők elvégzésére, a helyzet elfogadására, pihenésre és szórakozásra irányul. A 10. számú táblázatból kiderül, hogy a vírushelyzet miatti korlátozásokat alapjában véve a vizsgált minta elfogadja, és valamelyest alkalmazkodni tud a tanulás és egyéb teendök terén. Általánosan kijelenthető, hogy elégedettség övezi az életminőséget, azonban a pihenés, alvás nem mindenkinek kielégítő. Arra is fény derült, hogy a szórakozásra, mint szabadidős tevékenységre továbbra is igény van, legalábbis gondolati szinten.

10. táblázat - A funkcionális jólét jellemzői

\begin{tabular}{|c|c|c|c|c|c|c|c|c|c|c|}
\hline & \multicolumn{2}{|c|}{$\begin{array}{c}\text { Egyáltalán nem } \\
\text { igaz }\end{array}$} & \multicolumn{2}{|c|}{ Egy kicsit igaz } & \multicolumn{2}{|c|}{$\begin{array}{c}\text { Valamennyire } \\
\text { igaz }\end{array}$} & \multicolumn{2}{|c|}{$\begin{array}{c}\text { Meglehetősen } \\
\text { igaz }\end{array}$} & \multicolumn{2}{|c|}{$\begin{array}{l}\text { Nagyon } \\
\text { igaz }\end{array}$} \\
\hline $\begin{array}{l}\text { Képes vagyok } \\
\text { tanulni, dolgozni }\end{array}$ & 0 & $0,0 \%$ & 3 & $21,4 \%$ & 4 & $28,6 \%$ & 5 & $35,7 \%$ & 2 & $14,3 \%$ \\
\hline $\begin{array}{l}\text { Elfogadom a } \\
\text { helyzetet }\end{array}$ & 1 & $7,1 \%$ & 1 & $7,1 \%$ & 2 & $14,3 \%$ & 5 & $35,7 \%$ & 5 & $35,7 \%$ \\
\hline $\begin{array}{l}\text { Elégedett vagyok } \\
\text { életem eddigi } \\
\text { minőségével }\end{array}$ & 1 & $7,1 \%$ & 1 & $7,1 \%$ & 3 & $21,4 \%$ & 8 & $57,1 \%$ & 1 & $7,1 \%$ \\
\hline Jól alszom & 3 & $21,4 \%$ & 1 & $7,1 \%$ & 3 & $21,4 \%$ & 4 & $28,6 \%$ & 3 & $21,4 \%$ \\
\hline $\begin{array}{l}\text { Szórakozásra is } \\
\text { tudok gondolni }\end{array}$ & 0 & $0,0 \%$ & 0 & $0,0 \%$ & 3 & $21,4 \%$ & 8 & $57,1 \%$ & 3 & $21,4 \%$ \\
\hline
\end{tabular}


Az eloszlási görbét tekintve az összesített funkcionális változókra vonatkozóan (4. sz. ábra) megfigyelhető a jobbra tolódás, vagyis az alanyok hozzáállása pozitív, mondhatni reményteli hozzáállása.

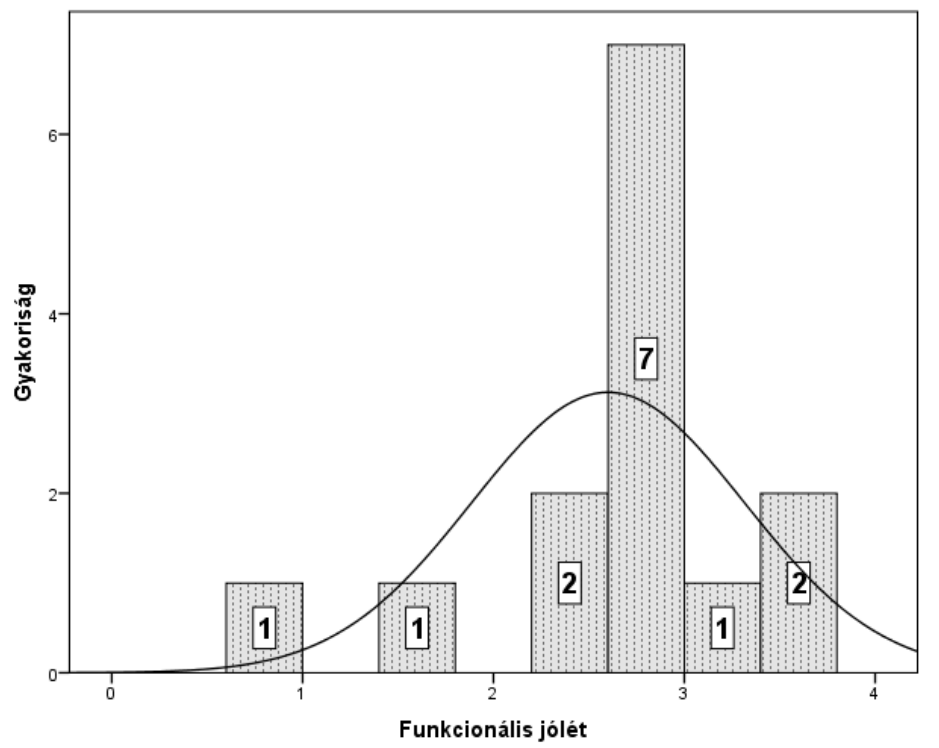

4. ábra - A funkcionális jólét hisztogram típusú ábrázolása az szórási görbével

Az eloszlás további vizsgálata során az 11-es táblázatot tekintve, az átlagokból kiderül, hogy a legmagasabb értéke a szórakozás gondolatának (vágy) van, a korlátozó intézkedések okozta helyzet elfogadása mellett. Észrevételezendő, hogy a helyzet elfogadása tekintetében elég nagy a szórás, eltérés van a megkérdezettek igényei között a szórakozást illetően. Visszatérve az alvásra, mivel itt a legnagyobb a szórás, ez szintén alátámasztja azon megállapításunkat, hogy korántsem mondható általánosnak a jó pihenés. Hozzátennénk, hogy ennek lehetséges oka a helyzettel való megküzdésért tett erőfeszítések okozta kimerültség mellett, a szabad levegőn végzett testmozgás hiánya lehet, melyre gyakorlatilag alanyainknak nem volt lehetősége a kijárási korlátozások miatt.

11. táblázat - A funkcionális jólét átlagainak és szórásának vizsgálata

\begin{tabular}{lcc}
\hline & Átlag & Szórás (SD) \\
\hline Képes vagyok tanulni, dolgozni & 2,43 & 1,02 \\
\hline Elfogadom a helyzetet & 2,86 & 1,23 \\
\hline $\begin{array}{l}\text { Elégedett vagyok életem eddigi } \\
\text { minőségével }\end{array}$ & 2,50 & 1,02 \\
\hline Jól alszom & 2,21 & 1,48 \\
\hline Szórakozásra is tudok gondolni & 3,00 & 0,68 \\
\hline Összesített funkcionális jólét & 2,60 & 0,72 \\
\hline
\end{tabular}

A funkcionális jólétet jellemző változók közötti összefüggéseket Pearson féle korrelációs számításokkal vizsgáltuk.

12. táblázat - A funkcionális jólétet leíró változók közötti korrelációs összefüggések

\begin{tabular}{lcccc}
\hline & $\begin{array}{c}\text { Elfogadom a } \\
\text { helyzetet }\end{array}$ & $\begin{array}{c}\text { Elégedett } \\
\text { vagyok életem } \\
\text { eddigi } \\
\text { minőségével }\end{array}$ & Jól alszom & $\begin{array}{c}\text { Szórakozásra is tudok } \\
\text { gondolni }\end{array}$ \\
\hline $\begin{array}{l}\text { Képes vagyok tanulni, } \\
\text { dolgozni }\end{array}$ & .053 & .297 & .447 & .223 \\
\hline Elfogadom a helyzetet & & .490 & .356 & É2.368 \\
\hline
\end{tabular}


Elégedett vagyok életem

eddigi minőségével

*. A korreláció .05 szinten szignifikáns (kétvégü).

**. A korreláció .01 szinten szignifikáns (kétvégü).

A funkcionális jólétet leíró változók között nem találtunk szignifikáns korrelációs viszonyokat, amint ez a 12-es táblázatból kitünik.

\subsection{A változócsoportok közötti összefüggések}

Az egyes csoportok (fizikai állapot, család és barátokkal való viszony, érzelmi jólét, funkcionális jólét és érzelmi élet) változóit egy 5 fokozatú skálán mértük, ahol alanyaink az egyáltalán nem igaz és nagyon igaz közötti fokozatok közül választhattak. A válaszok alapján kiszámoltuk a csoportok átlagértékét. A fizikai állapot $(\mathrm{M}=1.36, \mathrm{SD}=.79)$ és az érzelmi jólét $(\mathrm{M}=1.83, \mathrm{SD}=.5)$ mutatták a legkisebb átlagokat, ami a kijárási tilalom okozta otthonmaradásnak, a mozgás hiányával és a társas élet hiányával magyarázható. Az érzelmi élet, vagyis az érzelmi állapotok $(\mathrm{M}=2.36, \mathrm{SD}=1.51)$ átlaga magasabb az érzelmi jóléténél, ami azzal magyarázható, hogy az érzelmi jólét a változó érzelmi állapotok eredményeként alakul ki. Az adatokból tehát igazolják, hogy a bezártság nem tesz jót a léleknek. A családdal és barátokkal $(\mathrm{M}=2.24, \mathrm{SD}=.42)$ való viszony az érzelmi életre jellemző átlagértékhez közelít, mivel ez is egy viszonylag állandó állapot. A funkcionális jólét $(\mathrm{M}=2.6$, $\mathrm{SD}=.72$ ) értéke viszont a fizikai állapotot és érzelmi jólétet jellemző változókhoz képest magasabb. Az öt változócsoport között Pearson féle korrelációs összefüggéseket kerestünk. A korrelációs mủveleteknél a csoporton belüli változók átlagértékeit vettük alapul.

13. sz. táblázat - A változócsoportok közötti korrelációs értékek

\begin{tabular}{lllll}
\hline & Család és barátok & Érzelmi Jólét & Funkcionális Jólét & Érzelmi Élet \\
\hline Fizikai állapot & .496 & $.894^{* *}$ & $.576^{*}$ & .530 \\
\hline Család és barátok & & $.602^{*}$ & .254 & .252 \\
\hline Érzelmi Jólét & & .429 & $.566^{*}$ \\
\hline Funkcionális Jólét & & & .528 \\
\hline$* *$ A korreláció .01 szinten szignifikáns (kétvégü). & & \\
$*$ A korreláció .05 szinten szignifikáns (kétvégü). & & \\
\hline
\end{tabular}

A fenti 13. sz. táblázatból kitünik, hogy a fizikai állapot és az érzelmi jólét erős pozitív korrelációs viszonyban állnak $(\mathrm{r}=.894, \mathrm{p}<.01)$, tehát aki meg tudta őrizni érzelmi egyensúlyát, annak jó maradt a fizikai állapota is. A fizikai állapot és a funkcionális jólét közepesen erös, pozitív korrelációs viszonyban állnak $(\mathrm{r}=.576, \mathrm{p}<.05)$, vagyis az erőnlét feltétele a müködőképességnek. Az érzelmi jólét összefüggésben áll a családdal és barátokkal való viszonnyal, a korrelációs együttható közepesen erös, pozitív ( $\mathrm{r}=.602, \mathrm{p}<.05)$. Az összefüggés jelzi a jó kapcsolatok fontosságát, amelyek az érzelmi harmónia alapját képezik. Az érzelmi élet jellemzői, vagyis a hangulati változások és az érzelmi jólét is közepesen erős pozitív korrelációs viszonyban állnak $(\mathrm{r}=.566, \mathrm{p}<.05)$. Ha a személy képes az érzelmi kontrollra, nem hagyja elragadtatni magát szélsőséges érzésektől, és próbálja megtartani az érzelmi egyensúlyt, ez együtt jár az érzelmi jólét pozitív minőségével.

\section{Következtetések}

A koronavírus első hulláma, a kijárási tilalom és tiltások ellenére, ami kihívást jelentett - egy olyan foglalkozási kategória számára is, akik képzésüknek köszönhetően, felkészültebben néztek szembe a helyzettel, mint azok, akik nem vettek részt egészségfejlesztő tréningeken - a pozitív egészségmagatartás gyakorlásának következtében nem okozott testi-lelki károsodást.

A megkérdezett diákok életmódja és életformája teljesen megváltozott. Az oktatás és a szakmai gyakorlat online zajlott. Fel kellett adják a megszokott tevékenységeik nagy részét, és visszakerültek a szülői kontroll hatása alá. Az új helyzetben fel kellett találniuk magukat, ami a megváltozott 
környezettel és az új elfoglaltságokkal való megbékélést, az új napirend kialakítását, az erőforrások mozgósítását feltételezte.

A megkérdezett személyek nem hagyták el magukat, hanem tettek azért, hogy a krízis helyzetet elfogadják, aktivitással válaszoltak a kihívásokra, ez előnyökkel járt az alkalmazkodás tekintetében, egészségvédő szerepe volt. Kontroll csoport hiányban nem tudunk pontos összehasonlítást végezni, de más kutatásokból tudjuk, hogy a bezártság nagyon sok ember számára testi-lelki károsodáshoz vezetett (Váradi, Ferenci, Falus 2020; Vasiliu 2020; Zamfir és Zamfir 2020).

A kvantitatív adatok feldolgozása azt mutatta, hogy a fizikai állapot kapta a legkisebb átlagokat, ami arra enged következtetni, hogy ennél a változónál következett be a legnagyobb állapotromlás. A fiziológiás müködések nem szenvedték kárát a bezártságnak. Komolyabb alvászavar, a pszichoszomatikus tünetek, fájdalmak hiánya volt a jellemző. Az érzelmi jólét mutatójának értéke a családdal és barátokkal való viszony átlagértével hasonlatos. Ez azt jelenti, (amit a naplókból is kiolvashattunk), a bezártság ideje alatt a társas kapcsolatok kielégítőek maradtak. A funkcionális jólét értéke viszont a fizikai állapotot és érzelmi jólétet jellemző változókhoz képest magasabb, ami azt jelenti, hogy a jó fizikai és érzelmi állapot ellenére nem volt könnyü fenntartani a müködöképes állapotot. Optimálisan kellett motiválják magukat ahhoz, hogy egyaránt elvégezhessék egyetemi és házkörüli feladataikat.

A krízissel való megbirkózáshoz fel kell ismerni, hogy csakis tudatos átkeretezéssel, új napirend és szokások, az erőforrások mozgósítása által, a reziliencia fenntartásával, aktív viszonyulással lehet szembenézni. Fokozatosan élték át a krízissel való megküzdés egyes szakaszait, amíg eljutottak az elfogadáshoz, az újrarendeződéshez. Az önmagukra figyelés és az öngondoskodás segített abban, hogy a pandémia első hullámát testi-lelki egészségük, müködőképességük megörzése mellett sikerült átélniük. Ez a gyakorlat útmutató lehet más foglalkozási kategóriák számára is.

\section{Irodalomjegyzék}

Abelin, T., (1987): Approaches to health promotion and disease prevention. In T. Abelin T, Brzezniski, Z. J., Carstairs, D. L. V., (1987): Measurement in health promotion and protection. WHO Regional Publications; European Series No. 22. Copenhagen. 29-45.

Békés V., (2002): A reziliencia-jelenség avagy az ökologizálódó tudományok tanulságai egy ökologizált episztemológia számára. In Forrai G, Margitay T. (szerk.), Tudomány és történet Tanulmánykötet Fehér Márta tiszteletére, Typotex, Budapest. 215-228.

Caplan C., (1964): Principles of Preventive Psychiatry, Basic Books, Inc., New York.

Elnöki Dekrétum 195. sz. 2020 március 16. http://legislatie.just.ro/Public/DetaliiDocument/223831. (2020.05.22).

G-Faktor kérdőív. https://qol.thoracic.org/sections/instruments/fj/pages/fact-g.html (2020.03.13).

Katonai Rendelet 3. sz. 2020 március 24. http://legislatie.just.ro/Public/DetaliiDocument/224340 (2020.05.22).

Matarazzo, J. D., (1984): Behavioral health: A 1990 challenge for the healthsciences professions. In Matarazzo, J. D., Millner, N. E., Weis, S. M. és Herd, J. A. : Behavioral Health: A Handbook of Health Enhancement and Disease Prevention. 1984. John Wiley, New York. 3-40.

Simon T. (2009). Elmélkedések az egészségről és annak értékéröl. http://egeszsegtudomany.higienikus.hu/cikk/2009_1/Simon.pdf (2020.03.28).

Váradi A, Ferenci T, Falus A., (2020): A koronavírus okozta COVID-19-pandémia. Korábbi tapasztalatok és tudományos evidenciák 2020. március végén. Orvosi Hetilap. 161(17): 644-651.

Vasiliu, O. (2020). Impactul regimului de autoizolare/izolare/carantinare în contextul pandemiei Covid-19 asupra funcționării cotidiene și sănătăţii mentale- rezultatele unui chestionar online.

http://www.scumc.ro/impactul-regimului-de-autoizolare-izolare-carantinare-in-contextul-pandemieicovid-19-asupra-functionarii-cotidiene-si-sanatatii-mentale-rezultatele-unui-chestionar-online/. (2020.06.18). 
World Health Organization. Strengthening and adjusting public health measures throughout the COVID-19 transition phases. Policy considerations for the WHO European Region 24 April 2020. https://apps.who.int/iris/bitstream/handle/10665/332467/WHO-EURO-2020-690-40425-54211eng.pdf?sequence $=1 \&$ is Allowed $=y$ (2020.05.02).

Zamfir, C., \& Zamfir, E. (2020). Calitatea vieţii în timpul pandemiei: probleme şi politici de răspuns. Un punct de vedere sintetic. Rapoartele sociale ale ICCV. Academia Româna. București. http://www.iccv.ro/wp-content/uploads/2020/04/Raport-social-ICCV-27-aprilie-2020.pdf (2020.05.02).

\section{Szerzők}

Albert-Lőrincz Enikő - Babes-Bolyai University, Cluj Napoca, (Romania) E-mail: e.albert.lorincz@gmail.com

Albert-Lőrincz Csanád - Partium Christian University, Oradea, (Romania). E-mail: alcs@ gmx.net 
